\title{
ANTIAGING AND ANTIBACTERIAL EFFICIENCY OF COPPER ION ON CUT ROSE VASE LIFE (ROSA L. HYBRID)
}

\author{
NGUYEN LE ${ }^{1}$
}

${ }^{1}$ Affiliation not available

December 8, 2021

\author{
Le Nguyen ${ }^{1}$, Nguyen Thanh-Nho ${ }^{1, *}$, Le Trung-Hieu ${ }^{2}$, Nguyen Viet-Cuong ${ }^{1}$ \\ ${ }^{1}$ Faculty of Environmental and Food Engineering, Nguyen Tat Thanh University, Ho Chi Minh City, Viet- \\ nam \\ ${ }^{2}$ Ewater Engineering Co.Ltd, Vietnam.
}

${ }^{*}$ Corresponding author: ntnho@ntt.edu.vn

\section{Extended Abstract}

The plantation area and output of cut flowers are increasing worldwide. Post-harvest preservation is an important step of production to reduce losses and improve product quality, values, and competitiveness. Many preservation methods are applied to reduce the impact of adverse factors on the quality and shelf life of cut flowers after harvest. The main techniques include refrigeration, atmospheric, low pressure, and chemical conditions. Vietnam has three primary cut flower growing regions: the Red River Delta, Da Lat city (Lam Dong province, central highland), and the Mekong Delta. The flower is mainly cultivated in conditions without coverage. Only a tiny area of the experimental garden is covered using nylon, net, cork, bamboo, etc., to preserve flowers. The post-harvest preservation is almost based on spontaneous experiences, leading to a quantity loss that causes the increased cost of cut flowers in markets far from flower farms. The proliferation of bacteria in vase water in and on cut flowers is the main cause of the shortened lifespan of some cut flowers and foliage. Consequently, the vase life of cut flowers is decreased. Therefore, it is necessary to have suitable preservation for extending the freshness of cut flowers after harvesting and vases life to increase their values. In the present study, we used copper solutions to the cut rose vase to study its antiaging and antibacterial efficiency. Our hypothesis, metal ions dissolved in water at low concentrations can play as bactericides, fungicides, and wood preservatives [1-3]. Copper ions can create the necessary energy source for the operation of cells, from which the metabolism takes place quickly, helping to eliminate toxins and replace the new layer of healthier and more quality cells.

The morphological changes of flowers over the four stages (Table 1): (a) flowering stage, (b) full bloom stage, (c) flowering stage begins to wilt, (d) full wilted flower stage. The significance of evaluation is to find out which treatments can extend stages (a), (b), and slow down stages (c), (d). The results showed that stage (a) only occurred in the first two days, and stage (d) appeared in the last two days in the control solution. 
Meanwhile, stage (d) did not present in vases containing copper ions at concentrations of $1 \mathrm{mg} \mathrm{L}^{-1}$ and $3 \mathrm{mg}$ $\mathrm{L}^{-1}$ at the end of the experimental time. Besides, stage (c) appeared on the $8^{\text {th }}$ day of the experiment in vases with $1 \mathrm{mg} \mathrm{L} \mathrm{L}^{-1}$ of copper ion. Stage (a) lasted for the first three days, and stage (b) was maintained until the $8^{\text {th }}$ day with $3 \mathrm{mg} \mathrm{L}^{-1}$ of copper ion in vases. At the end of the experiment ( $9^{\text {th }}$ day), there were signs of stage (c). Similar observations were reported for cut Acacia holosericea by Kamani Ratnayake [4]. The lifespan of A. holosericea was improved with copper ion treatment. The petal shape and color assessment aimed to determine flower distinctness, uniformity, and stability during growth. The observed abnormalities explain the vulnerability as well as the ability to maintain growth in the tested subjects. The primary color on the inner petal side was still pink (P) to the end of the experiment using $1 \mathrm{mg} \mathrm{L}^{-1}$ and $3 \mathrm{mg} \mathrm{L}^{-1}$ of copper ion. Meanwhile, light yellow (P-Y), the color of the inner side of the petals, was recorded in the control vases. At the same time, the freshness was entirely lost at the end of the experiment with wilted yellow (Y) (Table 1). These phenomena may be related to water stress [5] or low carbohydrate concentrations [6]. In another observation for reflexing of petals one by one described as two signals as Absent (Ab.) and Present (Pr.), the "present" signal appeared from the $2^{\text {nd }}$ day for control vases during the testing process. For vases, copper concentrations using $1 \mathrm{mg} \mathrm{L}^{-1}$ and $3 \mathrm{mg} \mathrm{L}^{-1}$ appeared on the $6^{\text {th }}$ and $7^{\text {th }}$ day, respectively. Another important feature when observing growth in flower diameter was observed. In the present study, it was observed that the flower diameters on the last day of the experiment were in descending of using $3 \mathrm{mg} \mathrm{L}^{-1}$ of copper ion $>1 \mathrm{mg} \mathrm{L}^{-1}$ of copper ion > control vases without copper ion (i.e., ranging from $6.0 \mathrm{~cm}$ to 7.2 $\mathrm{cm}>$ from $6.2 \mathrm{~cm}$ to $6.8 \mathrm{~cm}>5.2 \mathrm{~cm}-5.5 \mathrm{~cm})$.

This study showed that copper ions have great promise as an antimicrobial agent, i.e., restricting the proliferation of coliforms. The rose vases containing copper ions at $1 \mathrm{mg} \mathrm{L}^{-1}$ and $3 \mathrm{mg} \mathrm{L}^{-1}$ exhibited superior anti-coliform activity, and better efficiency at copper ion level increased. We suggest that the copper ion were absorbed into the rose, increasing its antiaging and antibacterial ability. As a result, it was no significant difference in the residual copper ion concentration in the rose vases after 9 days of the investigation. The results were consistent with the recorded sensory states. The morphological change, color state, petal shape occurred slower on rose in vases using $3 \mathrm{mg} \mathrm{L}^{-1} \mathrm{Cu}^{2+}$ than others. Because of its color-changing from green to blue at a higher concentration of $3 \mathrm{mg} \mathrm{L}^{-1}$, we need to carefully evaluate the effects of $\mathrm{Cu}^{2+}$ on the flower appearance before use. To extend the application of metal ions for post-harvest preservation on the cut flower life, such as rose, a combination of different ions can provide a complete bactericidal effect preventing mixed bacterial populations.

Keywords: antibacterial, antiaging, cut flower, rose, copper ion.

\section{Acknowledegment}

This study was supported by Nguyen Tat Thanh University, Ewater Engineering Co.Ltd

\section{References}

[1]. S. Mittapally, R. Taranum, and S. Parveen, "Metal ions as antibacterial agents," Journal of Drug Delivery and Therapeutics 8, 411-419 (2018).

[2]. A. J. Macnish, R. T. Leonard, and T. A. Nell, "Treatment with chlorine dioxide extends the vase life of selected cut flowers," Postharvest Biology and Technology 50, 197-207 (2008).

[3]. W. G. Van Doorn, D. Zagory, and M. S. Reid, "Role of ethylene and bacteria in vascular blockage of cut fronds from the fern Adiantum raddianum," Scientia horticulturae 46, 161-169 (1991).

[4]. K. Ratnayake, D. C. Joyce, and R. I. Webb, "Investigation of potential antibacterial action for postharvest copper treatments of cut Acacia holosericea," Postharvest Biology and Technology 70, 59-69 (2012). 
[5]. R. E. Paull, "Temperature-induced leakage from chilling-sensitive and chilling-resistant plants," Plant Physiology 68, 149-153 (1981).

[6]. M. Reid, "Rose, spray rose, sweetheart rose-recommendations for maintaining postharvest quality," Produce Facts Article. Postharvest Technology research and Information Center, University of California, Davis 1, (2004). 